\title{
Systemic inflammation in chronic obstructive pulmonary disease
}

\author{
E-J.D. Oudijk, J-W.J. Lammers, L. Koenderman
}

Systemic inflammation in chronic obstructive pulmonary disease. E-J.D. Oudijk, J-W.J. Lammers, L. Koenderman. C ERS Journals Ltd 2003.

ABSTRACT: Chronic obstructive pulmonary disease (COPD) is characterised by a chronic inflammation in the pulmonary tissue. The disease is associated with a switch from a self-limiting inflammatory response, mainly initiated by smoke inhalation, to a chronic persistent inflammatory response after prolonged interaction with cigarette smoke. The extent of the inflammatory reaction is correlated with the severity of the disease.

Chronic inflammation in the pulmonary tissue is also associated with systemic effects. These effects range from cytokine-induced priming of peripheral leukocytes, to muscle wasting induced by cytokines such as tumour necrosis factor- $\alpha$. Despite a general consensus that chronic inflammation is a characteristic phenomenon of the disease, surprisingly little is known regarding the underlying pathogenetic mechanisms.

A clear communication is present between the disease mechanisms in the pulmonary compartment and peripheral tissues, leading to the concept of COPD as a systemic inflammatory disease. This communication can be mediated by: 1) leakage of reactive oxygen species and stress-induced cytokines directly into the peripheral blood, 2) (pre)activation of peripheral blood leukocytes that can result in aberrant homing and activation of inflammatory cells in distant tissues, and 3) the liberation of proinflammatory mediators by leukocytes and/or stromal cells present in the pulmonary tissues during progression of the disease.

The current authors hypothesise that the occurrence of a chronic inflammatory response after prolonged interaction of the pulmonary tissue with cigarette smoke causes aberrant homing of leukocytes to the tissue and delayed apoptosis. This leads to the autonomous characteristic of the inflammatory response in patients with chronic obstructive pulmonary disease.

Eur Respir J 2003; 22: Suppl. 46, 5s-13s.
Dept of Pulmonary Diseases, Heart Lung Center Utrecht, University Medical Center Utrecht, Utrecht, The Netherlands.

Correspondence: L. Koenderman

Dept of Pulmonary Diseases

F02.333

University Medical Centre Utrecht

Heidelberglaan 100

3584 CX Utrecht

The Netherlands

Fax: 31302505415

E-mail: L.Koenderman@hli.azu.nl

Keywords: Chronic obstructive pulmonary disease

systemic inflammation

Received and accepted June 302003
Chronic obstructive pulmonary disease (COPD) is a major worldwide health problem with an increasing prevalence and incidence [1, 2]. After many years of investigation, the pathophysiological processes leading to COPD are still poorly defined. In 1977 FletCHER and PETO [3] defined COPD as a chronic airflow obstructive and hypersecretory disorder with a strong relation to smoking. Since then, chronic irreversible airflow obstruction is a common hallmark in all definitions subsequently produced by the British Thoracic Society, the European Respiratory Society and the American Thoracic Society [4-6]. An important change in the definition is found in a more recent statement by the National Heart, Lung and Blood Institute (NHLBI)/World Health Organization (WHO) Global Initiative for Chronic Obstructive Lung Disease (GOLD). In this consensus report COPD is defined as "a disease state characterized by airflow limitation that is not fully reversible. The airflow limitation is usually both progressive and associated with an abnormal inflammatory response of the lungs to noxious particles and gases" [7]. It is now recognised that the inflammatory response of the lungs is an important field of research necessary for understanding the disease processes, and for the subsequent development of novel therapies for COPD.

The course of the disease can be divided into four different clinical stages according to the classification of the GOLD guidelines (fig. 1) [7]. The first two stages (at risk and mild COPD) are subclinical and hardly noticed by the patients.
Symptoms such as chronic cough and sputum production slowly increase, and can be recognised in all stages of COPD. Often COPD is diagnosed at the time that patients begin to

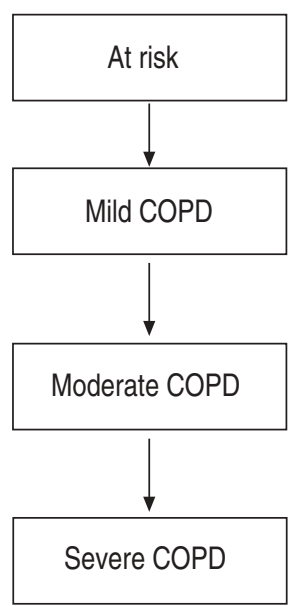

Normal spirometry/chronic symptoms (cough, sputum production)

$\mathrm{FEV}_{1} / \mathrm{FVC}<70 \% \mathrm{FEV}_{1} \leq 80 \%$ predicted. With or without chronic symptoms (cough, sputum, production)

$\mathrm{FEV}_{1} / \mathrm{FVC}<70 \%, 30 \% \leq \mathrm{FEV}_{1}<80 \%$ predicted. With or without chronic symptoms (cough, sputum, production, dyspnoea)

Fig. 1.-Classification of chronic obstructive pulmonary disease (COPD) by severity according to the Global Initiative for Chronic Obstructive Lung Disease (GOLD) guidelines [7]. FEV1: forced expiratory volume in one second; FVC: forced vital capacity. 
suffer from coughing, dyspnoea and a decrease in exercise tolerance. In these patients with moderate-to-severe COPD the disease has a considerable impact on the quality of life and daily activities. Apart from the gradual progression, COPD is associated with intermittent exacerbations. These exacerbations can be life threatening and patients are frequently admitted to the hospital. Exacerbations of COPD can be caused by different aetiologies such as infections with viruses and bacteria, or common pollutants and are associated with inflammatory changes within the respiratory tract [8-11].

The most important risk factor leading to the development of COPD is cigarette smoking. Fifteen to 20 per cent of all smokers develop clinically symptomatic COPD during their lifetime [12, 13]. Exposure to occupational dusts and chemicals, infections, and outdoor and indoor air pollution, are also contributing factors to the development of COPD [7]. For instance the occurrence of COPD among housewives in Mexico, Saudi Arabia, India and Iran can be explained by the exposure of indoor smoke due to domestic cooking fuels [14-17].

\section{Damage model}

For many years, studies regarding disease pathogenesis in COPD were focused on the pathophysiological changes within the airways and alveoli. As stated above, the most important factor leading to COPD is cigarette smoking. Several processes can be initiated due to smoking of cigarettes. Firstly, the development of direct damage of the lung tissue due to noxious particles in cigarette smoke and thermal injury. Secondly, direct activation of macrophages, neutrophils and resident cells by smoke particles and/or by the induction of repair processes [18-20]. Smoking of cigarettes induces damage of the lungs, which is followed by "normal" repair processes [21]. When the "normal" repair processes are hampered, aberrant tissue responses in the lungs can occur, resulting in the development of several features of the characteristic pathology seen in COPD [21, 22]. Two main hypotheses have been postulated explaining this aberrant tissue response: 1) an imbalance in the oxidant-antioxidant system, and 2) an imbalance between the action of proteases and antiproteases.

The imbalance of the oxidant-antioxidant system is a wellknown effect of smoking, and is associated with damage to the lungs. Normally, a delicate balance exists between the toxicity of oxidants and the protective antioxidant defence system [23]. Cigarette smoke can directly deplete antioxidants thereby shifting the balance towards oxidant burden [24, 25]. In addition, the increased numbers of inflammatory leukocytes and alveolar macrophages will significantly contribute to this increased pro-oxidant environment in the pulmonary tissue of patients with COPD (see below). Cigarette smoke contains a high concentration of reactive oxygen species (ROS) with $>10^{14}$ free radicals per inhaled puff [26]. This induction of oxidative stress by cigarette smoke-derived ROS will result in processes such as lipid peroxidation, neutrophil sequestration, inactivation of antiproteases and transcription of stress-related genes [26, 27]. These ROS have also been shown to cause severe damage to airway epithelial cells and other structures of the airways and alveoli. Outside the lung, tissue oxidative stress can have systemic effects by leakage of ROS to the circulation, or indirectly by induction of stressrelated products such as cytokines [28].

Under normal physiological conditions antiproteases are in balance with proteases. Cigarette smoke has the capacity to inactivate several antiproteases in the pulmonary tissue [29-32]. This will cause a decrease in the capacity of the pulmonary tissue to inactivate several proteases that are important in the normal tissue homeostasis in the lung [33, 34]. Smoking-induced emphysema is thought to be mediated in part by the prolonged and direct inhibition of antiproteases in the lung tissue $[29,31,32]$. A clear consequence is the risk that proteases, neutrophil elastase for example, can cause tissue injury under these conditions. Neutrophils, as part of the innate immune system, are an integral part of the immune surveillance on mucosal surfaces [35]. Proteases, including neutrophil elastase are important players in the killing reaction towards invading microorganisms. On the other hand "spilling" of these enzymes will have important consequences for host tissue damage provided that the enzymes are not properly inactivated in the tissues.

\section{Inflammation in the airways is a hallmark of the pathogenesis of COPD}

\section{Acute inflammation}

Besides the direct damage of the lung parenchyma by the production of ROS, a clear inflammatory process is seen in the pulmonary tissue of patients with COPD $[36,37]$. This is characterised by an influx of monocytes, neutrophils, CD8+ lymphocytes and sometimes eosinophils [38]. Apart from the production of ROS by a membrane bound reduced nicotinamide adenine dinucleotide phosphate (NADPH)-oxidase [27] these cells contribute to tissue damage by liberation of active proteolytic enzymes [39, 40]. The accumulation of macrophages in the alveoli, bronchioli and small airways is positively associated with the development of emphysema $[38,40,41]$. However, the mechanisms leading to degradation of extracellular matrix are incompletely understood. Serine proteases (e.g. neutrophil elastase) and metalloproteinases (e.g. matrix metalloproteinases (MMPs)) have been suggested to be responsible for this process [42-45]. Neutrophil elastase, proteinase, cathepsin B and MMPs have indeed been shown to produce emphysematous lesions in animal studies [46-49]. The release of proteolytic enzymes by inflammatory cells contributes to the protease/antiprotease imbalance. This imbalance is enhanced by a decrease in antiproteases like $\alpha_{1}$-protease inhibitor and secretory proteinase inhibitor, which are inactivated by oxidants (see above).

\section{Chronic inflammation in lung tissue of COPD patients}

Progression of COPD is characterised by an intense chronic inflammation of the lungs [50]. Long-term tissue damage and acute inflammation induced by noxious particles both contribute to this switch to a chronic persistent inflammation. Although some details regarding pathogenesis of inflammation in COPD have been identified, a large gap in knowledge is present regarding the role of the inflammatory cells in the origin and the progression of the disease. Biopsy studies in COPD patients showed an increase of neutrophils and CD8+ cytotoxic lymphocytes in the mucosal epithelium and macrophages in the subepithelium [38, 51]. Macrophages can be directly activated by cigarette smoke and are therefore thought to play a critical role in sustaining the chronic inflammation in the pulmonary tissue of COPD patients [20]. Neutrophils can subsequently participate by responding to chemotactic factors released by macrophages, epithelial cells, and other resident cells [18, 19]. Activated neutrophils and macrophages can then contribute to the development of tissue damage and emphysema by the release of ROS and proteinases $[40,52,53]$. 
Studies of alveolar septal wall remodelling in mild-tomoderate emphysema show a loss of total tissue, interstitial thickening, and increased numbers of interstitial fibroblasts and interstitial macrophages [54]. It is relevant to note that tissue remodelling is less obvious when compared to pulmonary tissue in allergic asthma [55]. It is generally accepted that chronic inflammation and remodelling are intrinsically related $[7,55,56]$. However, the mechanisms responsible for this remodelling are ill defined, but they seem orchestrated by mucosal fibroblasts [22, 57]. It is therefore tempting to speculate that the increased numbers of leukocytes in the bronchial tissues are important in the breakdown of tissue in chronic inflammatory lesions. Chronic repair of these lesions leads to long-term activation of fibroblasts resulting in tissue remodelling.

As chronic inflammation is an important process in COPD, pro-inflammatory mediators of such as chemokines (e.g. interleukin (IL)-8) and cytokines (e.g. tumour necrosis factor (TNF)- $\alpha$ ), will probably play an important role in the pathogenesis of COPD. These modulators of immune cell function are found in sputum and bronchoalveolar lavage (BAL) fluid of COPD patients [58, 59]. The identification of these cytokines in plasma/serum of COPD patients strongly suggests that the local inflammatory response communicates via these mediators with the systemic circulation. Prolonged liberation of these mediators can be viewed as the generator of systemic effects in COPD patients.

\section{Systemic effects initiated by the local persistent inflammatory response in COPD}

\begin{abstract}
Activation of leukocytes in the peripheral blood by mediators originating from the local inflammatory response
\end{abstract}

Cytokines can directly (pre)activate peripheral blood leukocytes. Several lines of evidence show that the peripheral leukocyte population is activated in patients with chronic inflammatory pulmonary diseases. In allergic asthma several studies demonstrate the activation of eosinophils in the peripheral blood [60-62]. In COPD, activation of peripheral blood neutrophils has also been shown [63]. This activation is subtle and is characterised by potentiation of migratory and cytotoxic responses. $[64,65]$ This process is generally referred to as priming [63]. The priming of leukocytes is essential for and precedes their extravasation to the tissues [63]. In addition, priming is essential for optimal activation of cytotoxic mechanisms in granulocytes initiated by physiological stimuli [66-68]. Therefore, cytokine/chemokine-induced (pre)activation is likely to be essential for the maintenance and progression of the inflammatory processes in the lungs.

A general consensus is present regarding the pathogenetic role of granulocytes in chronic inflammatory diseases in the lung. The situation with monocytes is less clear as these cells are progenitors of macrophages and are involved in normal tissue repair [69]. Monocytes accumulate in the lungs of smokers in response to cigarette smoke [20]. Probably, smokeactivated macrophages release monocytic chemokines (e.g. monocyte chemoattractant protein (MCP)-1) into the peripheral blood [19, 70]. Apart from the recruitment of cells to the lung, these chemokines contribute to the priming of, and to the increased expression of, CD43 and CD11b receptors on monocytes found in the peripheral blood of COPD patients [71, 72]. Priming of monocytes contributes to the homing of these cells to their target organs such as the inflammatory loci in the lungs. However, the risk for aberrant homing of these cells to tissue sites outside the inflammatory loci also increases and monocytes can thus be involved in pathogenetic tissue responses. A clear example is the role of monocytes in coronary heart disease and atherosclerosis [71, 73]. The incidence of these clinical conditions is clearly increased in patients with COPD [74, 75]. It remains to be established whether these processes are causally linked.

It is not only the pre-activation of leukocytes that is increased in the peripheral blood of patients with chronic inflammatory pulmonary diseases, but also the absolute numbers of leukocytes. This latter phenomenon is not restricted to COPD patients but is also found in "healthy" smokers. Many studies have found a correlation between the leukocyte count in the peripheral blood and the current smoking status [76-79]. Epidemiological studies regarding the effect of smoking cessation on granulocyte counts in "healthy" smokers showed a relatively fast recovery during the first 2 yrs after quitting. However, for lymphocytes and monocytes effects of smoking could be observed up to $5 \mathrm{yrs}$ after cessation of smoking [76].

Neutrophils are important effector cells in COPD and can mediate systemic effects of chronic inflammation

Increased numbers of neutrophils have been found in the airways of "healthy" smokers without COPD in comparison with healthy nonsmoking controls [80, 81]. Cigarette smoke exposure in rabbits caused an increased number of granulocytes in the peripheral blood similar to that seen in humans. The bone marrow was indirectly stimulated by the cigarette smoke and this resulted in a faster transit time of granulocyte differentiation and proliferation through the post-mitotic pool, and accelerated the release of both mature and immature cells [81]. This is probably caused by the local release of cytokines by the cigarette-exposed lungs. These cytokines can subsequently mediate the communication between the inflamed tissue and the bone marrow.

NOGUERA et al. [82] showed increased ROS production and gene expression of adhesion molecules (macrophage antigen (MAC)-1) on neutrophils isolated from patients with COPD and "healthy" smokers, compared to cells from normal nonsmoking individuals. This increased expression of adhesion molecules is correlated with an increased respiratory burst. Studies concerning the effects of cigarette smoke on neutrophils show additional effects on priming of the peripheral blood neutrophils [83, 84]. An increase of the expression of MAC-1 (CD11b/CD18) and formyl-methionylleucyl-phenylalanine (fMLP) receptors on neutrophils was demonstrated after stimulation of peripheral blood neutrophils with cigarette smoke condensate [82]. A role for the intracellular activation of mitogen-activated protein kinase pathways was shown by the blocking effect of the p38 inhibitor SB203580 on the expression of CD11b/18 and fMLP receptors [84]. These results suggest that neutrophils can be directly primed by cigarette smoke. Interestingly, in COPD patients who stopped smoking, the airway inflammation was not repressed and ongoing and was associated with a continuous activation of circulating neutrophils [85, 86]. Taken together, these studies suggest that smoking alone is involved in changes in the activation state of peripheral blood neutrophils from COPD patients and "healthy" smokers [82, 83].

In addition to the probable direct effect of cigarette smoke, the increase in circulating cytokines is responsible for a hyper-reactive state of the neutrophil. As mentioned before, TNF- $\alpha$ has been found in increased amounts in BAL and sputum samples of COPD patients [87, 88]. The increased production of TNF- $\alpha$ by cells in the inflamed lung may contribute to priming of inflammatory cells [83]. In patients 
with COPD an increase of the soluble TNF- $\alpha$ receptors in the peripheral blood has also been demonstrated [59, 89]. In another study performed in COPD patients in comparison with healthy controls, the present authors found an increase of soluble TNF- $\alpha$ receptor (sTNF $\alpha-\mathrm{R} 55)$ in the peripheral blood of the COPD patients (fig. 2). However, in plasma no correlation was observed between forced expiratory volume in one second (FEV1) and TNF $\alpha-\mathrm{R} 55$. On the other hand in sputum, VERNOOY et al. [59] found a negative correlation between sTNF $\alpha-R 55$ and FEV1. Furthermore an inverse correlation with chronic hypoxaemia and circulating TNF- $\alpha$ levels was found in COPD by TAKABATAKe et al. [90]. Preliminary studies in the current authors' group have confirmed the importance of cytokines such as TNF- $\alpha$ in the peripheral blood of COPD patients. E.H.J.N (Dermatology/Allergology Dept, University Medical Centre Utrecht, Utrecht, The Netherlands; personal communication) and colleagues showed an increase in activation status of peripheral blood neutrophils in patients with COPD. Neutrophil messenger ribonucleic acid (mRNA) expression of CD83, a marker for TNF- $\alpha$ - or lipopolysaccharide-stimulated neutrophils, was found to be elevated in peripheral blood neutrophils of COPD patients irrespective of the smoking status. The activation of peripheral blood neutrophils was related to disease severity. The observation of low mRNA CD83 expression in "healthy" current smoking individuals suggests that smoking of cigarettes did not activate peripheral neutrophils in these subjects.

The potential importance of TNF- $\alpha$ led researchers to investigate whether there is an association between TNF- $\alpha$ polymorphisms and disease severity in COPD. Several studies regarding the TNF- $\alpha 308$ polymorphism showed a correlation between the presence of this polymorphism and the occurrence of COPD [91-93]. SAKAO and coworkers [91, 92] found an increase in this TNF- $\alpha$ polymorphism in a group of patients with severe emphysema, compared to a group with less severe emphysema. Increased incidence of TNF- $\alpha$ polymorphisms was also found in COPD patients compared to healthy controls $[91,92]$.

In conclusion, the increased number of neutrophils in the lungs of patients with COPD, the increased priming of neutrophils in peripheral blood and the increase in TNF- $\alpha$ and STNF- $\alpha$ receptors suggest an important role for a TNF- $\alpha$ /

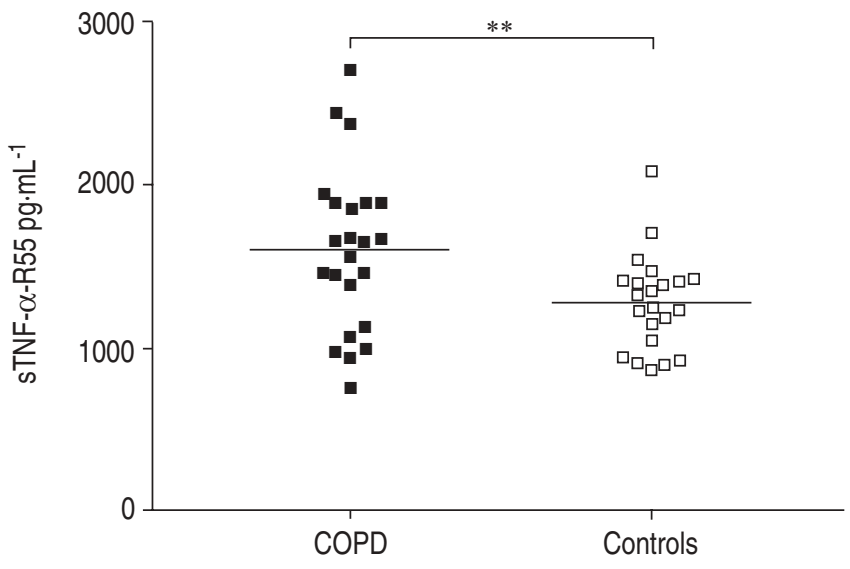

Fig. 2. - Soluble TNF- $\alpha$ receptor $55(\mathrm{sTNF}-\alpha \mathrm{R} 55)\left(\mathrm{pg} \cdot \mathrm{mL}^{-1}\right)$ measured in serum of 23 patients with mild-to-severe chronic obstructive pulmonary disease (COPD) (mean forced expiratory volume in one second $\left(\mathrm{FEV}_{1}\right) 53.9 \pm 4.2 \%$ of predicted; Global Initiative for Chronic Obstructive Lung Disease (GOLD) class 1-3) compared with 22 healthy nonsmoking controls (mean FEV $100.9 \pm 2.5 \%$ of pred). sTNF $\propto$ R55 was determined by an enzyme-linked immunosorbent assay. Statistical analysis was performed by Mann-Whitney U-test. $* *: \mathrm{p}<0.01$. neutrophil axis in the maintenance of the COPD phenotype [94]. It is, therefore, tempting to speculate that future treatment of certain COPD phenotypes should be focused on antagonism of the processes that are instrumental for the interaction between neutrophils and TNF- $\alpha$. So far no human data are available in the context of COPD. It should, however, be noted that antagonism of TNF- $\alpha$ has proven to be very successful in the treatment in groups of patients with rheumatoid arthritis and Crohn's disease (see below) [95-97]. The question also remains whether this therapy will ever prove to be cost-effective in COPD.

\section{Muscle wasting and weight loss initiated by chronic inflammatory processes in COPD}

COPD is increasingly considered as a complex disease involving the participation of several organs $[98,99]$. The local inflammatory processes in the lungs can affect peripheral tissues either by direct effects of released cytokines and chemokines, or indirectly, via (pre)activation of peripheral inflammatory cells. Despite the general consensus regarding this issue, remarkably little is known about the underlying mechanisms.

COPD is clearly associated with a progressive loss of muscle mass and function. This is also seen in many other chronic diseases such as cancer, congestive heart failure, rheumatoid arthritis, and acquired immunodeficiency syndrome (AIDS) [100-102]. Decrease in muscle function contributes to weakness, fatigue and has a negative influence on the prognosis of the COPD patient. Muscle wasting is a very complex clinical condition and is a consequence of various physiological processes such as a change in metabolism, protein synthesis and breakdown, and at a cellular level an imbalance in proliferation, differentiation and survival $[103,104]$. The central cytokine in the loss of muscle mass is TNF- $\alpha$ released by epithelial cells, macrophages and activated neutrophils [104]. Different mechanisms are involved in the TNF- $\alpha$ induced muscle loss. Firstly, TNF- $\alpha$ induces a direct stimulation of protein loss in the skeletal muscle cells [68, 105]. Secondly, TNF- $\alpha$ stimulates apoptosis via interaction with the TNF- $\alpha$ receptor present on the muscle cells. Several signalling pathways have been shown to be involved in this process including Fas-associated proteins, jun-N-terminal kinases and the nuclear factor (NF)- $\kappa \mathrm{B}$ pathway $[105,106]$. Thirdly, loss of muscle cells is induced via the modulation of the TNF- $\alpha / N F-\kappa B$ signalling due to $\operatorname{ROS}[105,107]$. The importance of the ROS induced $\mathrm{TNF}-\alpha / \mathrm{NF}-\kappa \mathrm{B}$ signalling pathway in regulating the muscle injury, however, is still unclear [105].

\section{Persistent chronic inflammation}

A critical point in the development of COPD is the switch from a physiological self-limiting inflammation to a persistent irreversible chronic inflammation. Surprisingly little is known regarding this transition. It is, however, tempting to speculate about the following model. In the early stages of COPD, physiological inflammatory reactions are associated with initial repair processes induced by the damage of the airway tissue by cigarette smoke. In the majority of smokers this smoking-induced physiological inflammation is self limiting and clinical disease does not develop. In this situation monocytes and neutrophils are found in the sputum and tissue, but their function seems to be limited to normal repair processes. However, they have the potential to cause a chronic but subclinical inflammatory phenotype after prolonged 
smoking [76, 77]. A critical characteristic of this condition is the fact that it is reversible upon cessation of smoking. In a relatively large subpopulation $(15-20 \%)$ of smokers this selflimiting reversible response switches to an irreversible inflammatory process. This inflammation has clear characteristics of an autonomous process since cessation of smoking does not lead to the resolution of inflammation.

Not much is known regarding the regulation of this autonomous inflammation. However, recent data show that stromal cells, such as fibroblasts and epithelial cells, are instrumental in this process. Stromal cells can produce a multitude of pro- and anti-inflammatory molecules. It has been demonstrated that inflamed epithelium is an important source of chemokines and cytokines [57, 58, 88, 108]. The production of chemokines and cytokines by the epithelial cells and fibroblasts can also have systemic effects similar to the production of these mediators by tissue leukocytes.

Leukocyte extravasation to the inflamed lungs is regulated by complex interaction between adhesion ligands on activated endothelial cells and adhesion receptors expressed on preactivated leukocytes [109-111]. Several of these molecules are regulated at the level of protein expression. A clear example is the expression of selectins on both endothelial cells and leukocytes. However, the function of other adhesion molecules is modulated by a second level of regulation. This socalled inside-out control causes a switch to high functionality of these receptors [112]. It is induced by inflammatory mediators either in soluble form or presented at the surface of activated endothelial cells [113].

An increased endothelial expression of the adhesion molecules intercellular adhesion molecule (ICAM)-1 and E-selectin has been found in smokers [114-116]. Expression and activation of CD11b on peripheral blood leukocytes, together with the endothelial expression of adhesion molecules ICAM-1 and E-selectin, will result in an increased adhesion and transmigration through endothelial cells [71, 72]. These processes can be potentiated by the production of cytokines by stromal cells. In vitro studies with smoke extractstimulated fibroblasts showed an heterogeneous amount of cytokines and chemokines such as IL-8, granulocyte colonystimulating factor and MCP-1, that can affect both bystander cells and leukocytes [19, 20].

The mechanisms underlying the switch from an acute and self-limiting inflammation to a chronic persistent inflammation in patients with COPD are currently poorly defined. However, much can be learned from the clinical picture of rheumatoid arthritis (RA). RA is a chronic inflammatory disease which, like COPD, is characterised by an inflammatory infiltrate in the affected joints. Elevated levels of chemokines have been found in RA patients. These chemokines are thought to be the modulators of the inflammatory processes in this disease [117, 118]. Increased numbers of T-cells and monocytes dominate in the inflamed joints. Differential expression of chemokine receptors has been found on monocytes in peripheral blood, synovial fluid and synovial tissue in patients with RA compared with cells from normal donors [119]. Also on T-cells a different expression of chemokine receptors was found. Aberrant accumulation of leukocytes at inflammatory sites has been shown to be due to the expression of a certain set of chemokine receptors on the inflammatory cells interacting with the production of certain chemokines at tissue sites [117]. This "postal code" hypothesis is very helpful in understanding how a limited amount of chemokines can be involved in homing of many leukocyte subtypes to a multitude of different tissue sites. Importantly, it predicts the possibility that aberrant expression of these chemokines/receptors leads to aberrant homing ("cells gone astray at certain tissue sites") as suggested by BUCKLEY et al. [120].
It is not only aberrant homing but also increased survival of these cells that contribute to the chronic and persistent inflammation. Delay in apoptosis of T-cells, found by SALMON et al. [121] is a contributing factor to the persistent inflammation in RA. This increased survival of cells was induced by the abnormal synovial microenvironment. In conclusion, the persistent inflammatory infiltrate in RA is based on sustained and aberrant recruitment of cells as a consequence of the increased chemokine production by stromal cells, upregulation of chemokine receptors on the inflammatory cells and the enhanced survival. Important for the persistence of these processes are the stromal factors, which are associated with the local microenvironment [122].

\section{Conclusion}

Novel insights into the mechanisms underlying the chronic persistent inflammatory reaction in COPD leads to new hypotheses that can help designing new therapeutic targets. COPD appears to start as a reversible self-limiting inflammatory reaction as seen in all smoking individuals (fig. 3a) mediated by both monocytes and neutrophils (fig. 3b). This part of the disease has characteristics of a "damage and repair" type of response. After prolonged exposure to cigarette smoke a "switch to chronicity" takes place and an irreversible inflammatory reaction is initiated which is clearly associated with neutrophils in the lung tissue. Not much is known regarding the underlying mechanism, but this chronic inflammation is clearly associated with systemic effects on distant tissues (fig. 3c).

If chronic persistent COPD is indeed in part mediated by the aberrant production of inflammatory mediators by stromal cells such as epithelial cells and fibroblasts this will

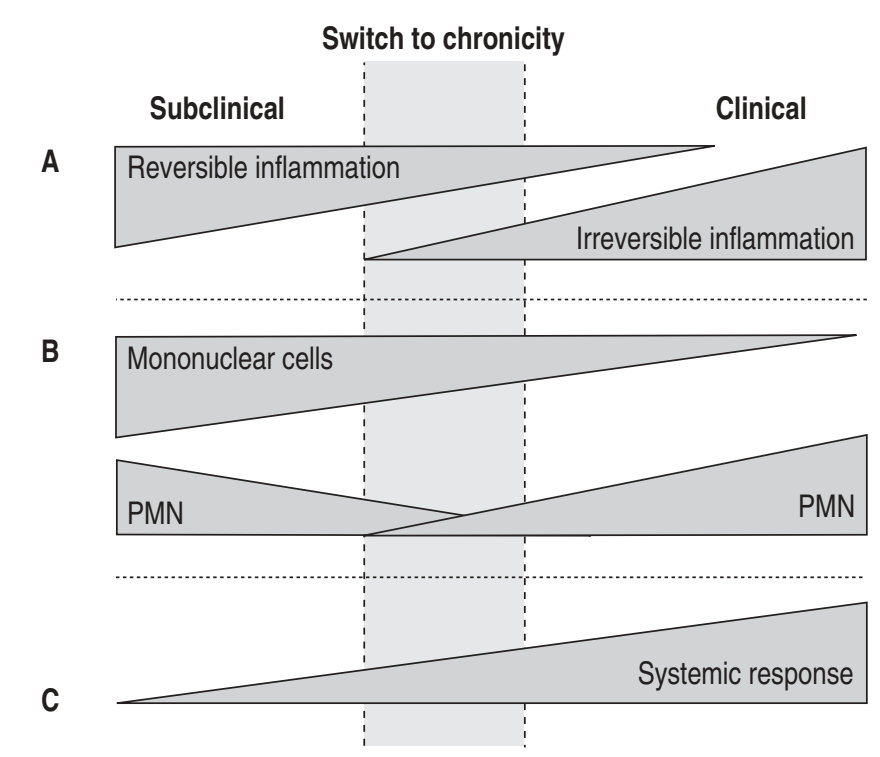

Fig. 3. - Model for disease progression in chronic obstructive pulmonary disease (COPD). The subclinical stage of COPD which can last up to $20 \mathrm{yrs}$ or more is characterised by a mainly reversible inflammation (Global Initiative for Chronic Obstructive Lung Disease (GOLD) severity stages at risk to mild COPD, panel A). Hereafter, the disease gradually progresses, becomes irreversible due to a chronic inflammatory reaction. During the switch to chronicity clinical symptoms become more prominent (GOLD stage mild COPD to severe COPD) (panel A). The subclinical phase of the disease is characterised by a reversible inflammatory reaction mediated by mononuclear and polymorphonuclear (PMN) leukocytes (panel B). During the progression of COPD a chronic and persistent inflammation develops systemic effects (panel C). 
have important consequences for future therapy. It has been shown that epithelial cells obtained from COPD patients produce high amounts of cytokines such as IL-8 and IL-6 $[123,124]$. In addition in BAL fluid of chronic asthma patients the amount of IL-8 is not down-regulated by steroids [124]. Therefore, it is tempting to speculate that epithelial cells are refractory to treatment with corticosteroids. Interestingly, many forms of COPD are not very responsive to the treatment with (inhaled) steroids [125-128]. An alternative repertoire of chemokine receptors on target cells in the peripheral blood is induced by an aberrant production of chemokines and cytokines in the pulmonary tissue of COPD patients. These two changes might result in the inappropriate homing of cells that have no function and go astray at these tissue sites. When the stromal microenvironment allows these cells to survive, an "aspecific" chronic inflammation can occur. This putative mechanism might also explain the occurrence of CD8+ T-cells in the pulmonary tissue of COPD patients with no apparent function. The use of corticosteroids is typically very effective in T-cell driven adaptive immune responses. It is not clear which effects these steroids have on the stromal microenvironment in chronic persistent inflammatory lesions in COPD. Several studies have demonstrated that steroids can induce survival of neutrophils [129-131], which are typically associated with more severe COPD. Therefore, it is important to define the role of corticosteroids on the mechanisms occurring in the stromal microenvironment.

Taken together, insight into the regulation of the inflammatory response in the lung and the communication of this process with distant tissues in chronic inflammatory diseases such as chronic obstructive pulmonary disease is starting to evolve. It is now critical to elucidate the mechanisms underlying the switch and maintenance of this chronic autonomous process in order to identify new therapeutic targets in this systemic disease.

\section{References}

1. Hurd S. The impact of COPD on lung health worldwide: epidemiology and incidence. Chest 2000; 117: 1s-4s.

2. National Heart LaBI. Morbidity \& Mortality: 2002 Chartbook on Cardiovascular, Lung and Blood Diseases. www.nhlbi.nih.gov/resources/docs/02_chtbk. pdf 2002. Date updated: May 2002; Date accessed: November 2002.

3. Fletcher C, Peto R. The natural history of chronic airflow obstruction. BMJ 1977; 1: 1645-1648.

4. BTS guidelines for the management of chronic obstructive pulmonary disease. The COPD Guidelines Group of the Standards of Care Committee of the BTS. Thorax 1997; 52: Suppl. 5, 1s-28s.

5. Standards for the diagnosis and care of patients with chronic obstructive pulmonary disease. American Thoracic Society. Am J Respir Crit Care Med 1995; 152: S77-S121.

6. Siafakas NM, Vermeire $\mathrm{P}$, Pride NB, et al. Optimal assessment and management of chronic obstructive pulmonary disease (COPD). The European Respiratory Society Task Force. Eur Respir J 1995; 8: 1398-1420.

7. Pauwels RA, Buist AS, Calverley PM, Jenkins CR, Hurd SS. Global strategy for the diagnosis, management, and prevention of chronic obstructive pulmonary disease. NHLBI/ WHO Global Initiative for Chronic Obstructive Lung Disease (GOLD) Workshop summary. Am J Respir Crit Care Med 2001; 163: 1256-1276.

8. Wedzicha JA. Exacerbations: etiology and pathophysiologic mechanisms. Chest 2002; 121: 136s-141s.

9. Lieberman D, Gelfer Y, Varshavsky R, Dvoskin B, Leinonen M, Friedman MG. Pneumonic vs nonpneumonic acute exacerbations of COPD. Chest 2002; 122: 1264-1270.
10. Patel IS, Seemungal TA, Wilks M, SJ, Donaldson GC, Wedzicha JA. Relationship between bacterial colonisation and the frequency, character, and severity of COPD exacerbations. Thorax 2002; 57: 759-764.

11. Sethi S, Evans N, Grant BJ, Murphy TF. New strains of bacteria and exacerbations of chronic obstructive pulmonary disease. $N$ Engl J Med 2002; 347: 465-471.

12. Scanlon PD, Connett JE, Waller LA, Altose MD, Bailey WC, Buist AS. Smoking cessation and lung function in mild-to-moderate chronic obstructive pulmonary disease. The Lung Health Study. Am J Respir Crit Care Med 2000; 161: 381-390.

13. Rennard SI, Daughton DM. Smoking cessation. Chest 2000; 117: 360s-364s.

14. Perez-Padilla R, Regalado J, Vedal S, et al. Exposure to biomass smoke and chronic airway disease in Mexican women. A case-control study. Am J Respir Crit Care Med 1996; 154: 701-706.

15. Dossing M, Khan J, al-Rabiah F. Risk factors for chronic obstructive lung disease in Saudi Arabia. Respir Med 1994; 88: 519-522.

16. Behera D, Jindal SK, Malhotra HS. Ventilatory function in nonsmoking rural Indian women using different cooking fuels. Respiration 1994; 61: 89-92.

17. Amoli K. Bronchopulmonary disease in Iranian housewives chronically exposed to indoor smoke. Eur Respir J 1998; 11: 659-663.

18. Hunninghake GW, Crystal RG. Cigarette smoking and lung destruction. Accumulation of neutrophils in the lungs of cigarette smokers. Am Rev Respir Dis 1983; 128: 833-838.

19. Sato E, Koyama S, Takamizawa A, et al. Smoke extract stimulates lung fibroblasts to release neutrophil and monocyte chemotactic activities. Am J Physiol 1999; 277: L1149L1157.

20. Shapiro SD. The macrophage in chronic obstructive pulmonary disease. Am J Respir Crit Care Med 1999; 160: S29-S32.

21. Rennard SI. Inflammation and repair processes in chronic obstructive pulmonary disease. Am J Respir Crit Care Med 1999; 160: S12-S16.

22. Wang H, Liu X, Umino T, et al. Cigarette smoke inhibits human bronchial epithelial cell repair processes. Am J Respir Cell Mol Biol 2001; 25: 772-779.

23. Barnes PJ. Chronic obstructive pulmonary disease. $N$ Engl $J$ Med 2000; 343: 269-280.

24. Alberg A. The influence of cigarette smoking on circulating concentrations of antioxidant micronutrients. Toxicology 2002; 180: 121-137.

25. Gokkusu C, Ademoglu E, Tamer S, Alkan G. Oxidantantioxidant profiles of platelet rich plasma in smokers. Addict Biol 2001; 6: 325-330.

26. Rahman I, MacNee W. Role of oxidants/antioxidants in smoking-induced lung diseases. Free Radic Biol Med 1996; 21: 669-681.

27. Repine JE, Bast A, Lankhorst I. Oxidative stress in chronic obstructive pulmonary disease. Oxidative Stress Study Group. Am J Respir Crit Care Med 1997; 156: 341-357.

28. MacNee W, Rahman I. Is oxidative stress central to the pathogenesis of chronic obstructive pulmonary disease? Trends Mol Med 2001; 7: 55-62.

29. Dhami R, Gilks B, Xie C, Zay K, Wright JL, Churg A. Acute cigarette smoke-induced connective tissue breakdown is mediated by neutrophils and prevented by alpha1antitrypsin. Am J Respir Cell Mol Biol 2000; 22: 244-252.

30. Dhami R, Zay K, Gilks B, Porter S, Wright JL, Churg A. Pulmonary epithelial expression of human alpha1-antitrypsin in transgenic mice results in delivery of alphal-antitrypsin protein to the interstitium. J Mol Med 1999; 77: 377-385.

31. Janoff A, Carp H. Possible mechanisms of emphysema in smokers: cigarette smoke condensate suppresses protease inhibition in vitro. Am Rev Respir Dis 1977; 116: 65-72.

32. Janoff A, George-Nascimento C, Rosenberg S. A genetically 
engineered, mutant human alpha-1-proteinase inhibitor is more resistant than the normal inhibitor to oxidative inactivation by chemicals, enzymes, cells, and cigarette smoke. Am Rev Respir Dis 1986; 133: 353-356.

33. Wright JL, Farmer SG, Churg A. Synthetic serine elastase inhibitor reduces cigarette smoke-induced emphysema in guinea pigs. Am J Respir Crit Care Med 2002; 166: 954 960.

34. Carp H, Miller F, Hoidal JR, Janoff A. Potential mechanism of emphysema: alpha 1-proteinase inhibitor recovered from lungs of cigarette smokers contains oxidized methionine and has decreased elastase inhibitory capacity. Proc Natl Acad Sci USA 1982; 79: 2041-2045.

35. Stockley RA. Neutrophils and the pathogenesis of COPD. Chest 2002; 121: 151s-155s.

36. Maestrelli P, Saetta M, Mapp CE, Fabbri LM. Remodeling in response to infection and injury. Airway inflammation and hypersecretion of mucus in smoking subjects with chronic obstructive pulmonary disease. Am J Respir Crit Care Med 2001; 164: S76-S80.

37. Cosio MG, Guerassimov A. Chronic obstructive pulmonary disease. Inflammation of small airways and lung parenchyma. Am J Respir Crit Care Med 1999; 160: S21-S25.

38. Jeffery PK. Comparison of the structural and inflammatory features of COPD and asthma. Giles F Filley Lecture. Chest 2000; 117: 251s-260s.

39. Stockley RA. Neutrophils and protease/antiprotease imbalance. Am J Respir Crit Care Med 1999; 160: S49-S52.

40. Tetley TD. Macrophages and the pathogenesis of COPD. Chest 2002; 121: 156s-159s.

41. Finkelstein R, Fraser RS, Ghezzo H, Cosio MG. Alveolar inflammation and its relation to emphysema in smokers. $\mathrm{Am}$ J Respir Crit Care Med 1995; 152: 1666-1672.

42. Zhu YK, Liu XD, Skold CM, et al. Synergistic neutrophil elastase-cytokine interaction degrades collagen in threedimensional culture. Am J Physiol Lung Cell Mol Physiol 2001; 281: L868-L878.

43. Turino GM. The origins of a concept: the proteaseantiprotease imbalance hypothesis. Chest 2002; 122: 10581060.

44. Ohnishi K, Takagi M, Kurokawa Y, Satomi S, Konttinen YT. Matrix metalloproteinase-mediated extracellular matrix protein degradation in human pulmonary emphysema. Lab Invest 1998; 78: 1077-1087.

45. Shapiro SD. Animal models for COPD. Chest 2000; 117: $223 \mathrm{~s}-227 \mathrm{~s}$

46. Lucey EC, Stone PJ, Breuer R, et al. Effect of combined human neutrophil cathepsin $G$ and elastase on induction of secretory cell metaplasia and emphysema in hamsters, with in vitro observations on elastolysis by these enzymes. Am Rev Respir Dis 1985; 132: 362-366.

47. Kao RC, Wehner NG, Skubitz KM, Gray BH, Hoidal JR. Proteinase 3. A distinct human polymorphonuclear leukocyte proteinase that produces emphysema in hamsters. $J$ Clin Invest 1988; 82: 1963-1973.

48. Lesser M, Padilla ML, Cardozo C. Induction of emphysema in hamsters by intratracheal instillation of cathepsin B. $\mathrm{Am}$ Rev Respir Dis 1992; 145: 661-668.

49. Zheng T, Zhu Z, Wang Z, et al. Inducible targeting of IL-13 to the adult lung causes matrix metalloproteinase- and cathepsin-dependent emphysema. J Clin Invest 2000; 106: 1081-1093.

50. Turato G, Zuin R, Miniati M, et al. Airway inflammation in severe chronic obstructive pulmonary disease: relationship with lung function and radiologic emphysema. Am J Respir Crit Care Med 2002; 166: 105-110.

51. O'Shaughnessy TC, Ansari TW, Barnes NC, Jeffery PK. Inflammation in bronchial biopsies of subjects with chronic bronchitis: inverse relationship of CD8+ T lymphocytes with FEV1. Am J Respir Crit Care Med 1997; 155: 852-857.

52. Churg A, Zay K, Shay S, et al. Acute cigarette smoke-induced connective tissue breakdown requires both neutrophils and macrophage metalloelastase in mice. Am J Respir Cell Mol Biol 2002; 27: 368-374.

53. Piotrowski WJ, Marczak J. Cellular sources of oxidants in the lung. Int J Occup Med Environ Health 2000; 13: 369-385.

54. Vlahovic G, Russell ML, Mercer RR, Crapo JD. Cellular and connective tissue changes in alveolar septal walls in emphysema. Am J Respir Crit Care Med 1999; 160: 20862092.

55. Jeffery PK. Remodeling in asthma and chronic obstructive lung disease. Am J Respir Crit Care Med 2001; 164: S28-S38.

56. Tiddens H, Silverman M, Bush A. The role of inflammation in airway disease: remodeling. Am J Respir Crit Care Med 2000; 162: S7-S10.

57. Knight D. Epithelium-fibroblast interactions in response to airway inflammation. Immunol Cell Biol 2001; 79: 160-164.

58. de Boer WI, Sont JK, van Schadewijk A, Stolk J, van Krieken JH, Hiemstra PS. Monocyte chemoattractant protein 1 , interleukin 8 , and chronic airways inflammation in COPD. J Pathol 2000; 190: 619-626.

59. Vernooy JH, Kucukaycan M, Jacobs JA, et al. Local and systemic inflammation in patients with chronic obstructive pulmonary disease: soluble tumor necrosis factor receptors are increased in sputum. Am J Respir Crit Care Med 2002; 166: $1218-1224$.

60. Mengelers HJ, Maikoe T, Brinkman L, Hooibrink B, Lammers JW, Koenderman L. Immunophenotyping of eosinophils recovered from blood and BAL of allergic asthmatics. Am J Respir Crit Care Med 1994; 149: 345-351.

61. Warringa RA, Mengelers HJ, Kuijper PH, Raaijmakers JA, Bruijnzeel PL, Koenderman L. In vivo priming of plateletactivating factor-induced eosinophil chemotaxis in allergic asthmatic individuals. Blood 1992; 79: 1836-1841.

62. Koenderman L, Coffer PJ. Controlling allergic inflammation by signaling regulation of eosinophils. Allergy 2001; 56: 204 214.

63. Koenderman L, Kanters D, Maesen B, et al. Monitoring of neutrophil priming in whole blood by antibodies isolated from a synthetic phage antibody library. J Leukoc Biol 2000; 68: 58-64.

64. Coffer PJ, Koenderman L. Granulocyte signal transduction and priming: cause without effect? Immunol Lett 1997; 57: 27-31.

65. Koenderman L, van der BT, Schweizer RC, et al. Eosinophil priming by cytokines: from cellular signal to in vivo modulation. Eur Respir J 1996; 9: Suppl. 22, 119s-125s.

66. Wyman TH, Bjornsen AJ, Elzi DJ, et al. A two-insult in vitro model of PMN-mediated pulmonary endothelial damage: requirements for adherence and chemokine release. Am J Physiol Cell Physiol 2002; 283: C1592-C1603.

67. Ernst M, Inglese M, Scholz GM, et al. Constitutive activation of the SRC family kinase Hck results in spontaneous pulmonary inflammation and an enhanced innate immune response. $J$ Exp Med R 2002; 196: 589-604.

68. Reid MB, Lannergren J, Westerblad H. Respiratory and limb muscle weakness induced by tumor necrosis factoralpha: involvement of muscle myofilaments. Am J Respir Crit Care Med 2002; 166: 479-484.

69. Riyami BM, Tree R, Kinsella J, et al. Changes in alveolar macrophage, monocyte, and neutrophil cell profiles after smoke inhalation injury. J Clin Pathol 1990; 43: 43-45.

70. Masubuchi T, Koyama S, Sato E, et al. Smoke extract stimulates lung epithelial cells to release neutrophil and monocyte chemotactic activity. Am J Pathol 1998; 153: 19031912.

71. Bergmann S, Siekmeier R, Mix C, Jaross W. Even moderate cigarette smoking influences the pattern of circulating monocytes and the concentration of sICAM-1. Respir Physiol 1998; 114: 269-275.

72. Kalra VK, Ying Y, Deemer K, Natarajan R, Nadler JL, Coates TD. Mechanism of cigarette smoke condensate induced adhesion of human monocytes to cultured endothelial cells. J Cell Physiol 1994; 160: 154-162. 
73. Saetta M, Turato G, Facchini FM, et al. Inflammatory cells in the bronchial glands of smokers with chronic bronchitis. Am J Respir Crit Care Med 1997; 156: 1633-1639.

74. Basili S, Ferroni P, Vieri M, et al. Lipoprotein(a) serum levels in patients affected by chronic obstructive pulmonary disease. Atherosclerosis 1999; 147: 249-252.

75. Jousilahti P, Vartiainen E, Tuomilehto J, Puska P. Symptoms of chronic bronchitis and the risk of coronary disease. Lancet 1996; 348: 567-572.

76. Van Tiel E, Peeters PH, Smit HA, et al. Quitting smoking may restore hematological characteristics within five years. Ann Epidemiol 2002; 12: 378-388.

77. Sunyer J, Munoz A, Peng Y, et al. Longitudinal relation between smoking and white blood cells. Am J Epidemiol 1996; 144: 734-741.

78. Freedman DS, Flanders WD, Barboriak JJ, Malarcher AM, Gates L. Cigarette smoking and leukocyte subpopulations in men. Ann Epidemiol 1996; 6: 299-306.

79. Freedman DS, Joesoef MR, Barboriak JJ, Stallone DD, Byers T. Correlates of leukocyte counts in men. Ann Epidemiol 1996; 6: 74-82.

80. Bosken $\mathrm{CH}$, Hards J, Gatter K, Hogg JC. Characterization of the inflammatory reaction in the peripheral airways of cigarette smokers using immunocytochemistry. Am Rev Respir Dis 1992; 145: 911-917.

81. Terashima T, Wiggs B, English D, Hogg JC, van Eeden SF. The effect of cigarette smoking on the bone marrow. Am J Respir Crit Care Med 1997; 155: 1021-1026.

82. Noguera A, Batle S, Miralles C, et al. Enhanced neutrophil response in chronic obstructive pulmonary disease. Thorax 2001; 56: 432-437.

83. Gustafsson A, Asman B, Bergstrom K. Cigarette smoking as an aggravating factor in inflammatory tissue-destructive diseases. Increase in tumor necrosis factor-alpha priming of peripheral neutrophils measured as generation of oxygen radicals. Int J Clin Lab Res 2000; 30: 187-190.

84. Koethe SM, Kuhnmuench JR, Becker CG. Neutrophil priming by cigarette smoke condensate and a tobacco antiidiotypic antibody. Am J Pathol 2000; 157: 1735-1743.

85. Rutgers SR, Postma DS, ten Hacken NH, et al. Ongoing airway inflammation in patients with COPD who do not currently smoke. Chest 2000; 117: 262s.

86. Turato G, Di Stefano A, Maestrelli P, et al. Effect of smoking cessation on airway inflammation in chronic bronchitis. Am J Respir Crit Care Med 1995; 152: 1262-1267.

87. Keatings VM, Collins PD, Scott DM, Barnes PJ. Differences in interleukin-8 and tumor necrosis factor-alpha in induced sputum from patients with chronic obstructive pulmonary disease or asthma. Am J Respir Crit Care Med 1996; 153: $530-534$

88. Chung KF. Cytokines in chronic obstructive pulmonary disease. Eur Respir J 2001; 18: Suppl. 34, 50s-59s.

89. Dentener MA, Creutzberg EC, Schols AM, et al. Systemic anti-inflammatory mediators in COPD: increase in soluble interleukin 1 receptor II during treatment of exacerbations. Thorax 2001; 56: 721-726.

90. Takabatake N, Nakamura H, Abe S, et al. The relationship between chronic hypoxemia and activation of the tumor necrosis factor-alpha system in patients with chronic obstructive pulmonary disease. Am J Respir Crit Care Med 2000; 161: 1179-1184.

91. Sakao S, Tatsumi K, Igari $\mathrm{H}$, et al. Association of tumor necrosis factor-alpha gene promoter polymorphism with low attenuation areas on high-resolution $\mathrm{CT}$ in patients with COPD. Chest 2002; 122: 416-420.

92. Sakao S, Tatsumi K, Igari H, Shino Y, Shirasawa H, Kuriyama T. Association of tumor necrosis factor alpha gene promoter polymorphism with the presence of chronic obstructive pulmonary disease. Am J Respir Crit Care Med 2001; 163: 420-422.

93. Keatings VM, Cave SJ, Henry MJ, et al. A polymorphism in the tumor necrosis factor-alpha gene promoter region may predispose to a poor prognosis in COPD. Chest 2000; 118 : 971-975.

94. Lewis SA, Pavord ID, Stringer JR, Knox AJ, Weiss ST, Britton JR. The relation between peripheral blood leukocyte counts and respiratory symptoms, atopy, lung function, and airway responsiveness in adults. Chest 2001; 119: 105-114.

95. Aeberli D, Oertle S, Mauron H, Reichenbach S, Jordi B, Villiger PM. Inhibition of the TNF-pathway: use of infliximab and etanercept as remission-inducing agents in cases of therapy-resistant chronic inflammatory disorders. Swiss Med Wkly 2002; 132: 414-422.

96. Kalden JR. Emerging role of anti-tumor necrosis factor therapy in rheumatic diseases. Arthritis Res 2002; 4: Suppl. 2, S34-S40.

97. Bondeson J, Maini RN. Tumour necrosis factor as a therapeutic target in rheumatoid arthritis and other chronic inflammatory diseases: the clinical experience with infliximab (REMICADE). Int J Clin Pract 2001; 55: 211-216.

98. Wouters EF, Creutzberg EC, Schols AM. Systemic effects in COPD. Chest 2002; 121: 127S-130S.

99. Wouters EF. Chronic obstructive pulmonary disease. 5: Systemic effects of COPD. Thorax 2002; 57: 1067-1070.

100. Coats AJ. Origin of symptoms in patients with cachexia with special reference to weakness and shortness of breath. Int J Cardiol 2002; 85: 133-139.

101. Walsmith J, Roubenoff R. Cachexia in rheumatoid arthritis. Int J Cardiol 2002; 85: 89-99.

102. Baronzio G, Zambelli A, Comi D, et al. Proinflammatory and regulatory cytokine levels in AIDS cachexia. In Vivo 1999; 13: 499-502.

103. Anker SD, Sharma R. The syndrome of cardiac cachexia. Int $J$ Cardiol 2002; 85: 51-66.

104. Sharma R, Anker SD. Cytokines, apoptosis and cachexia: the potential for TNF antagonism. Int J Cardiol 2002; 85: 161-171.

105. Li YP, Schwartz RJ, Waddell ID, Holloway BR, Reid MB. Skeletal muscle myocytes undergo protein loss and reactive oxygen-mediated NF-kappaB activation in response to tumor necrosis factor alpha. FASEB $J$ 1998; 12: 871-880.

106. Ladner KJ, Caligiuri MA, Guttridge DC. TNF regulated biphasic activation of NF-kB is required for cytokineinduced loss of skeletal muscle gene products. $\mathrm{J}$ Biol Chem 2003; 24278: 2294-2303.

107. Langen RC, Schols AM, Kelders MC, Van Der Velden JL, Wouters EF, Janssen-Heininger YM. Tumor necrosis factoralpha inhibits myogenesis through redox-dependent and independent pathways. Am J Physiol Cell Physiol 2002; 283: C714-C721.

108. Davies D, Holgate S. Asthma: the importance of epithelial mesenchymal communication in pathogenesis. Inflammation and the airway epithelium in asthma. Int J Biochem Cell Biol 2002; 34: 1520 .

109. Ulfman LH, Joosten DP, van der Linden JA, Lammers JW, Zwaginga JJ, Koenderman L. IL-8 induces a transient arrest of rolling eosinophils on human endothelial cells. J Immunol 2001; 166: 588-595.

110. Ulfman LH, Kuijper PH, van der Linden JA, Lammers JW, Zwaginga JJ, Koenderman L. Characterization of eosinophil adhesion to TNF-alpha-activated endothelium under flow conditions: alpha 4 integrins mediate initial attachment, and E-selectin mediates rolling. J Immunol 1999; 163: 343-350.

111. Pettersen CA, Adler KB. Airways inflammation and COPD: epithelial-neutrophil interactions. Chest 2002; 121: 142S$150 \mathrm{~S}$.

112. Liddington $\mathrm{RC}$, Ginsberg $\mathrm{MH}$. Integrin activation takes shape. J Cell Biol 2002; 158: 833-839.

113. Baggiolini M. Chemokines and leukocyte traffic. Nature 1998; 392: 565-568.

114. Adams MR, Jessup W, Celermajer DS. Cigarette smoking is associated with increased human monocyte adhesion to endothelial cells: reversibility with oral L-arginine but not vitamin C. J Am Coll Cardiol 1997; 29: 491-497. 
115. Schaberg T, Rau M, Oerter R, et al. Expression of adhesion molecules in peripheral pulmonary vessels from smokers and nonsmokers. Lung 1996; 174: 71-81.

116. Schaberg T, Lauer C, Lode H, Fischer J, Haller H. Increased number of alveolar macrophages expressing adhesion molecules of the leukocyte adhesion molecule family in smoking subjects. Association with cell-binding ability and superoxide anion production. Am Rev Respir Dis 1992; 146: 1287-1293.

117. Godessart N, Kunkel SL. Chemokines in autoimmune disease. Curr Opin Immunol 2001; 13: 670-675.

118. Ruth JH, Rottman JB, Katschke KJJ, et al. Selective lymphocyte chemokine receptor expression in the rheumatoid joint. Arthritis Rheum 2001; 44: 2750-2760.

119. Katschke KJJ, Rottman JB, Ruth JH, et al. Differential expression of chemokine receptors on peripheral blood, synovial fluid, and synovial tissue monocytes/macrophages in rheumatoid arthritis. Arthritis Rheum 2001; 44: 1022-1032.

120. Buckley CD, Pilling D, Lord JM, Akbar AN, ScheelToellner D, Salmon M. Fibroblasts regulate the switch from acute resolving to chronic persistent inflammation. Trends Immunol 2001; 22: 199-204.

121. Salmon M, Scheel-Toellner D, Huissoon AP, et al. Inhibition of T cell apoptosis in the rheumatoid synovium. J Clin Invest 1997; 99: 439-446.

122. Douglas MR, Morrison KE, Salmon M, Buckley CD. Why does inflammation persist: a dominant role for the stromal microenvironment? Exp Rev Mol Med 2002. www. expertreviews.org/02005264h.htm. Date updated: September 12 2002; Date accessed: November 2002.

123. Levine SJ, Larivee P, Logun C, Angus CW, Shelhamer JH. Corticosteroids differentially regulate secretion of IL-6, IL-8, and G-CSF by a human bronchial epithelial cell line. $\mathrm{Am}$ J Physiol 1993; 265: L360-L368.
124. Nocker RET, Weller FR, Out TA, de Riemer MJ, Jansen HM, van der Zee JS. Effect of fluticasone propionate on inflammatory indices in bronchoalveolar lavage fluid and on bronchial hyperresponsiveness in patients with asthma. Airway Inflammation in Asthma. Studies on Allergen Challenge and Corticosteroid Treatment; Thesis. Wageningen, The Netherlands, Ponsen\&Looijen, 1998; 49-71.

125. Culpitt SV, Maziak W, Loukidis S, Nightingale JA, Matthews JL, Barnes PJ. Effect of high dose inhaled steroid on cells, cytokines, and proteases in induced sputum in chronic obstructive pulmonary disease. Am J Respir Crit Care Med 1999; 160: 1635-1639.

126. Burge PS, Calverley PM, Jones PW, Spencer S, Anderson JA, Maslen TK. Randomised, double blind, placebo controlled study of fluticasone propionate in patients with moderate to severe chronic obstructive pulmonary disease: the ISOLDE trial. BMJ 2000; 320: 1297-1303.

127. Effect of inhaled triamcinolone on the decline in pulmonary function in chronic obstructive pulmonary disease. $N$ Engl J Med 2000; 343: 1902-1909.

128. Barnes PJ. Inhaled corticosteroids are not beneficial in chronic obstructive pulmonary disease. Am J Respir Crit Care Med 2000; 161: 342-344.

129. Zhang X, Moilanen E, Kankaanranta H. Beclomethasone, budesonide and fluticasone propionate inhibit human neutrophil apoptosis. Eur J Pharmacol 2001; 431: 365-371.

130. Chilvers ER, Rossi AG, Murray J, Haslett C. Regulation of granulocyte apoptosis and implications for antiinflammatory therapy. Thorax 1998; 53: 533-534.

131. Meagher LC, Cousin JM, Seckl JR, Haslett C. Opposing effects of glucocorticoids on the rate of apoptosis in neutrophilic and eosinophilic granulocytes. $J$ Immunol 1996; 156: 4422-4428. 